\title{
COMPARISON OF SURGICAL TREATMENT RESULTS AND CLINICAL AND RADIOLOGICAL FINDINGS OF TIBIAL PLATEAU FRACTURES
}

\author{
Kehribar Lokman, ${ }^{1}$ Karapinar Levent ${ }^{2}$ \\ ${ }^{1}$ Department of Orthopedics and Traumatology, Gazi State Hospital, Samsun, Turkey \\ ${ }^{2}$ Tepecik Training and Research Hospital Izmir, Turkey
}

Primljen/Received 23. 01. 2019. god.

Abstract: Introduction: In this retrospective study, it was aimed to evaluate the correlation between operative treatment results and clinical and radiological findings of tibial plateau fractures.

Patients and Methods: Between 1996 and 2006, 33 knees were operated for tibia plateau fracture of 32 patients. 29 patients were male and 3 were female. Only 3 cases $(9.99 \%)$ were open tibial plateau fractures. The mean age was 45 years. Fractures classified using the Schatzker classification were: $17(52 \%)$ type $1,12(12 \%)$ type $2,9(27 \%)$ type 5 and $6(9 \%)$ type 6 . Patients following the period were at least 44 weeks and maximum 480 weeks (mean 60 weeks).

Results: The results of 33 patients were determined by the clinical and radiological system of Rasmussen. According to clinical findings, 17 cases were excellent, 9 were good, 6 were medium and 1 was poor. According to the radiological findings, 9 cases were excellent, 16 were good, 6 were medium and 2 were bad. The difference between clinical and radiological findings was analyzed with Pearson core analysis and statistically significant $(\mathrm{p}<0.005)$. Comparison was made according to the time between injury and operation and no statistically significant difference was found $(p>0.005)$. The analyzes of the grade of fracture and the degree of fracture were statistically significant ( $\mathrm{p}<0.005) .42 .4 \%$ of all patients had meniscus injury. Therefore, arthroscopy should be used with surgery.

Conclusion: Anatomic reduction, rigid fixation of the joint and early mobilization can reduce complications and improve the function of the knee joint in tibial plateau fractures.

Key Words: Anatomic reduction, tibial plateau fracture, surgery.
Prihvaćen/Accepted 16. 04. 2019. god.

\section{INTRODUCTION}

The knee joint is one of the strongest and important joints of the body and is directly affected by plateau fractures. As these fractures are intra-articular in nature, they affect the alignment, stability, and movement of the joint. In addition, as the knee is a complex joint with dense soft tissues, its related injuries are classified as complex injuries. The mechanism of fracture is mainly due to axial compressive forces with varus or valgus stress and these fractures are produced by high-energy traumas (1). The Schatzker classification, which was developed in 1979 based on the anteroposterior (AP) radiographs of a series of 94 patients, has been still widely used by orthopedic surgeons. This system classify tibial plateau fractures into six types and lateral plateau fractures typically present with depression, while medial plateau fractures typically present with split (2). In addition, these fractures usually lead to arthrosis of the knee joint and total knee arthroplasty is a usually performed procedure following the arthrosis after tibial plateau fractures $(3,4)$.

The main goal of treatment of plateau fractures is to recover the integrity of the articular surface and to improve the function of the articular activity with minimal injury. In 1825, Sir Astley Cooper first published experiences with a series of knee dislocations and treated tibial fractures with compressive bandage and early passive mobilization, irrespective of the fracture pattern (5). Later in the history, open reduction and plate-screw fixation and osteosynthesis gain popularity which is still the first-line treatment in tibial plateau fracture practice $(6,7)$.

In the present study, we present our experience with tibial plateau fractures and discuss the treatment approaches in the light of the literature data. 


\section{PATIENTS AND METHODS}

This retrospective study included a total of 33 knees of 32 patients who were operated due to tibial plateau fractures at No. 1 Orthopedics and Traumatology inpatient clinic of Izmir Tepecik Training and Research Hospital, Izmir, Turkey between 1996 and 2006. A written informed consent was obtained from each patient. The study protocol was approved by the Local Ethical Committee. The study was conducted in accordance with the principles of the Declaration of Helsinki.

According to the Schatzker classification, $17 \mathrm{ca}-$ ses were type I, four cases were type II, nine cases were type V, and three cases were type VI. Among all fractures, there were three open fractures. The most common cause was pedestrian accidents.

Seventeen knees were surgically treated with a percutaneous technique. A lateral and anterolateral incision was made in 13 patients, while an anteromedial incision was made in one patient. Extensile surgery was performed in one patient. No parapatellar incision was used in any of the patients. Grafting was applied in 12 patients. All grafts were spongious and harvested from the same side of the iliac crest. Postoperatively, partial weight bearing was allowed at 13 weeks, while full weight bearing was allowed at 18 weeks.

The modified Rasmussen's clinical and radiological criteria were used to evaluate the tibial plateau fractures. It consists of five categories including pain, walking capacity, extension, total range of motion, and stability. The total score is the sum of these five items, and the higher scores indicate the greater function. A score of 0-9 is defined as poor, 10-19 as fair, 20-26 as good, and 27-30 as excellent. In addition, the anatomical score consists of three categories including depression, condylar widening, and angulation. A score of 0-5 is defined as poor, 6-11 as fair, $12-17$ as good, and 18 as excellent.

\section{Statistical Analysis}

Statistical analysis was performed using the Statistical Package for the Social Sciences (SPSS) for Windows version 10.0 software (SPSS Inc., Chicago, IL, USA). Descriptive data were expressed in mean \pm standard deviation (SD), number and frequency. The Pearson's correlation analysis was used for radiological and clinical comparisons. The Kruskal-Wallis test was carried out to compare radiological and clinical scores according to the Schatzker classification. The Mann-Whitney U test was used for binary comparisons. A $p$ value of $<0.05$ was considered statistically significant with $95 \%$ confidence interval (CI).

\section{RESULTS}

Of the patients, 29 (87.9\%) were males and three (12.1\%) were females. The mean age was 45 (range, 18 to 63) years. The mean follow-up was 65 (range, 11 to 120) months.

According to the Rasmussen's radiological criteria, the mean score was 13.6 (range, 4 to 18) in all 33 knees. The result was excellent in nine (27.3\%), good in $16(48.5 \%)$, and poor in six (6.0\%) cases (Figure 1). According to the Rasmussen's clinical criteria, the mean score was 23.3 (range, 8 to 29). The result was excellent in $17(51.5 \%)$, good in nine (27.3\%), fair in six $(18.2 \%)$, and poor in one (3\%) cases (Figure 2).

In the radiological evaluation of the final AP and lateral graphies, the degree of depression, condylar widening, and angulation were calculated. The mean degree of depression was $3.87 \mathrm{~mm}$, the mean condylar widening was $4.1 \mathrm{~mm}$, and the mean angulation was

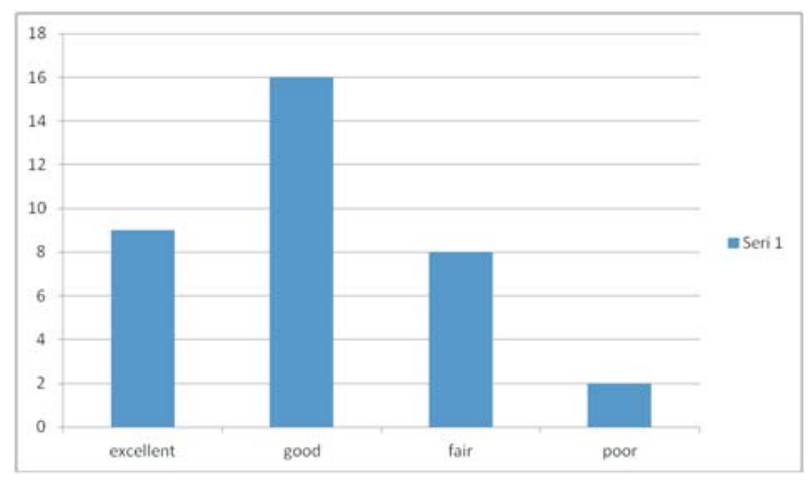

Figure 1. Rasmussen's radiological scores

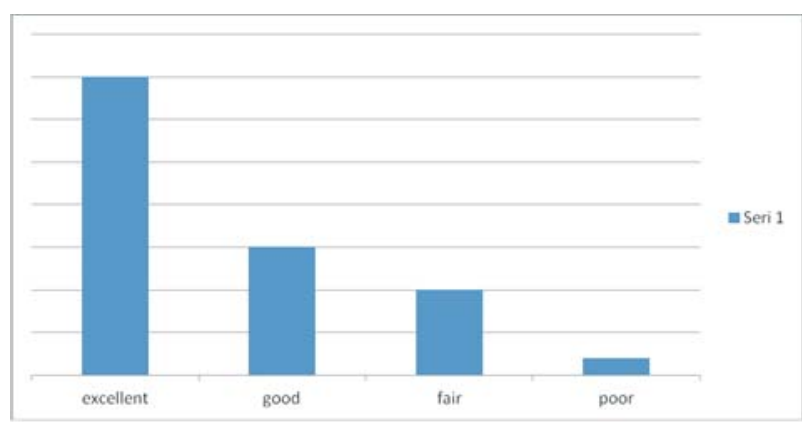

Figure 2. Rasmussen's clinical scores

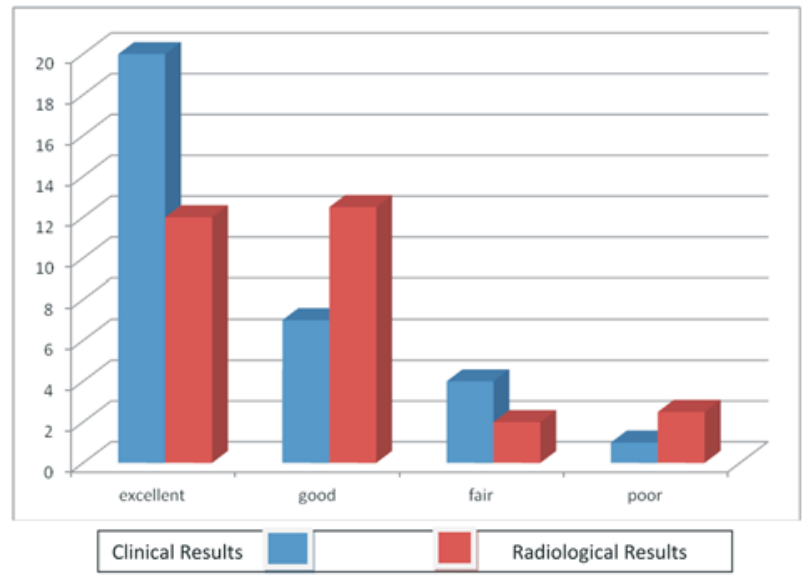

Figure 3. Comparison of the Rasmussen's clinical and radiological results 
3.7 in favor of valgus. In the final clinical evaluation, the mean extension loss was $7.3^{\circ}$ and the mean range of motion was $128^{\circ}$. In all patients, the knee was stable at $20^{\circ}$ flexion and full extension.

Based on the comparison of the clinical and radiological results, the clinical status of the patients was found to be correlated with the radiological status. In 12 patients $(36.4 \%)$, the clinical status was better than the radiological status, while the clinical and radiological statuses were equivalent in the remaining 19 patients (57.6\%) (Figure 3).

The Pearson's correlation analysis showed a positive correlation between the clinical scores and radiological scores $(r=0.754, p<0.001)$. In addition, according to the degree of depression (0-5 mm, 6-9 mm, or $\geq 10$ $\mathrm{mm}$ ), the mean clinical score was 25.947 and the mean radiological score was 5.789 in the $0-5 \mathrm{~mm}$ group $(\mathrm{n}=$ $19)$. In the 6-9 mm group $(\mathrm{n}=10)$, the mean clinical score was 0.500 and the mean radiological score was 12.4. Finally, the mean clinical score was 12.500 and the mean radiological score was 8.250 in the $\geq 10 \mathrm{~mm}$ group $(\mathrm{n}=4)$. According to the Kruskal-Wallis test, there was a significant difference in the clinical and radiological scores among the depression groups, indicating that the clinical and radiological scores decreased, as the degree of depression increased ( $<0.001$ for both) (Figure 4).

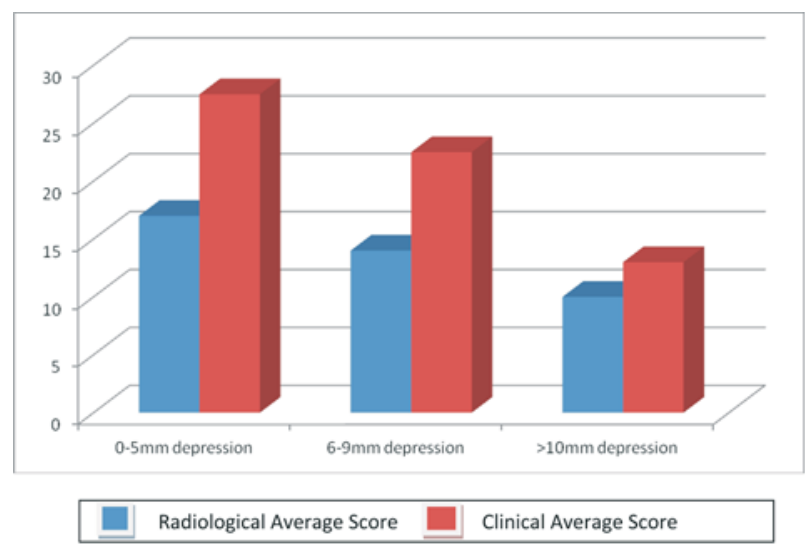

Figure 4. Clinical and radiological results according to depression degree

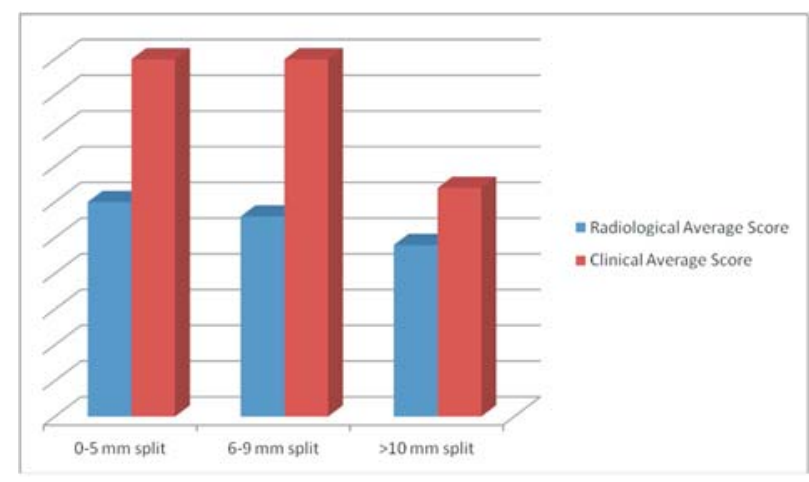

Figure 5. Clinical and radiological results according to split
According to the degree of cleavage $(0-5 \mathrm{~mm}, 6-9$ $\mathrm{mm}$, or $\geq 10$ ), the mean clinical score was 24.250 and the mean radiological score was 15.375 in the $0-5 \mathrm{~mm}$ group $(\mathrm{n}=16)$. In the $6-9 \mathrm{~mm}$ group, the mean clinical score was 24.091 and the mean radiological score was $13.818(n=11)$. Finally, the mean clinical score was 15.833 and the mean radiological score was 9.167 in the $\geq 10 \mathrm{~mm}$ group $(\mathrm{n}=6)$. According to the Kruskal-Wallis test, there was a significant difference in the clinical $(\mathrm{p}=0.022)$ and radiological scores $(\mathrm{p}=$ 0.019 ) among the cleavage groups, indicating that the clinical and radiological scores decreased, as the degree of cleavage increased (Figure 5).

\section{DISCUSSION}

Tibial plateau fractures are complex injuries involving not only the bone structure, but also the other connective tissue components such as the joint cartilage and meniscus, as they are intra-articular in nature.Considering the risk of osteoarthritis and degeneration, treatment of these fractures is of utmost importance.

Osteoporosis is a risk factor in tibial plateaufractures. In a case series, Su et al. reported osteoporosis were seen adult women aged $\geq 50$ years following the tibial plateaufractures (8). In our series, however, the number of female patients is not consistent with the literature with a male ratio of $87.9 \%$ and female ratio of $12.1 \%$. This discrepancy can be explained by the fact that our facility is a complex trauma center.

In the literature, there is no consensus on the surgical treatment of these fractures. Some authors have recommended conservative treatment, irrespective of the type of the fracture and advocated that reduction with conservative treatment yields satisfactory functional outcomes, but not anatomical outcomes $(9,10)$. On the other hand, some others have recommended surgical treatment, except for stable, non-displaced fractures. Surgery has several advantages including a smooth reduction of the joint surface, anatomical restoration of the limb axis, and stabile fixation with early mobilization. It is also indicated in the treatment of connective tissue and meniscus injuries which majorly affect the functional and anatomical outcomes $(11,12)$.

There are studies in the literature that they found no significant relationship between the depression and functional outcomes in the majority of cases with $\geq 10$ $\mathrm{mm}$ depression at the final visit $(13,14)$. However, Singleton et al. found a significant relationship between the degree of depression and uncorrectable valgus deformity and secondary osteoarthritis (4). In a case series including 60 patients, Blokker et al.achieved satisfactory results in $85 \%$ of cases undergoing anatomic reduction and in $75 \%$ of cases in a step of less than 5 $\mathrm{mm}$, although a step of greater than $5 \mathrm{~mm}$ was associa- 
ted with unsatisfactory results (15). In our study, we classified the degree of depression as 0-5 mm, 6-9 mm, and $\geq 10 \mathrm{~mm}$ and found poor clinical and radiological results with increased depression.

Rasmussen found a close relationship between varus angulation and osteoarthritis and suggested that alignment of the medial condyle, particularly,should be proper in double condylar fractures. In addition, the author reported that an evident malalignment of the tibial plateau surface and femoral condyle with uncorrectable tibial condylar widening was significantly associated with secondary osteoarthritis (16). In our study, good and excellent clinical and radiological outcomes were achieved in $72.7 \%$ of the patients. However, poor clinical and radiological results were obtained in one patient and two patients, respectively. In their study, Schatzker et al. also achieved acceptable outcomes in 32 of 94 (78\%) surgically treated patients and suggested that osteoporosis was a major factor affecting the outcome (2). In another case series involving 95 patients, Waddel et al. applied surgical treatment to 69 patients and achieved satisfactory results in $65 \%$ of these patients (17). Also, the authors further claimed that improved results could be obtained with grafting combined with internal fixation.

In the present study, postoperative complications were seen in three patients $(9.09 \%)$ including deep vein thrombosis in one patient and superficial infection in two patients. None of the patients experienced compartment syndrome, heterotopic ossification, or vessel injury. In a study, Kayiran et al. reported that the most common postoperative complication was heterotopic ossification (18). In another study, Rockwood found infection to be the major complication following surgery. To prevent infections, duration of surgery should be diminished, extraperiosteal dissection should be avoided, and prophylactic antibiotic therapy should be given (19). In our study population, one patient had a peroneal lesion preoperatively. Although the lesion was intraoperatively explored and released, the nerve function remained impaired. Of note, the lack of deep vein thrombosis or pulmonary embolism in any of the patients in our study, which are commonly reported in the literature, can be explained by individual genetic factors and the use of low-molecular-weight heparin prophylaxis in all patients.

Nonetheless, there are some limitations to this study. First, the results cannot be generalized to the overall population due to the small sample size and retrospective nature of the study. Second, there are many factors influencing the results of tibial plateau fractures.

In conclusion, clinicians should keep in mind that good clinical results can be achieved with surgery in tibial plateau fractures, even if radiological results are poor and, therefore, evaluation should not be based on radiological criteria alone. Based on our experience, we suggest ana- tomical and rigid fixation in the treatment of these fractures to provide early mobilization and to minimize dysfunction. However, further large-scale, long-term studies are needed to establish a conclusion.

Acknowledgment: None

Conflict of Interests: The authors declare that there are no conflicts of interest related to this article.

Funding: This research did not receive any specific grant from funding agencies in the public, commercial, or not-for-profit sectors.

\section{Licensing}

This work is licensed under a Creative Commons Attribution 4.0 International (CC BY 4.0) License.

\section{Case Sample}

46 years old male, Car accident, Schatzker Type 6 fracture

Preoperative, early postoperative and 1 year follow up X-rays are shown below

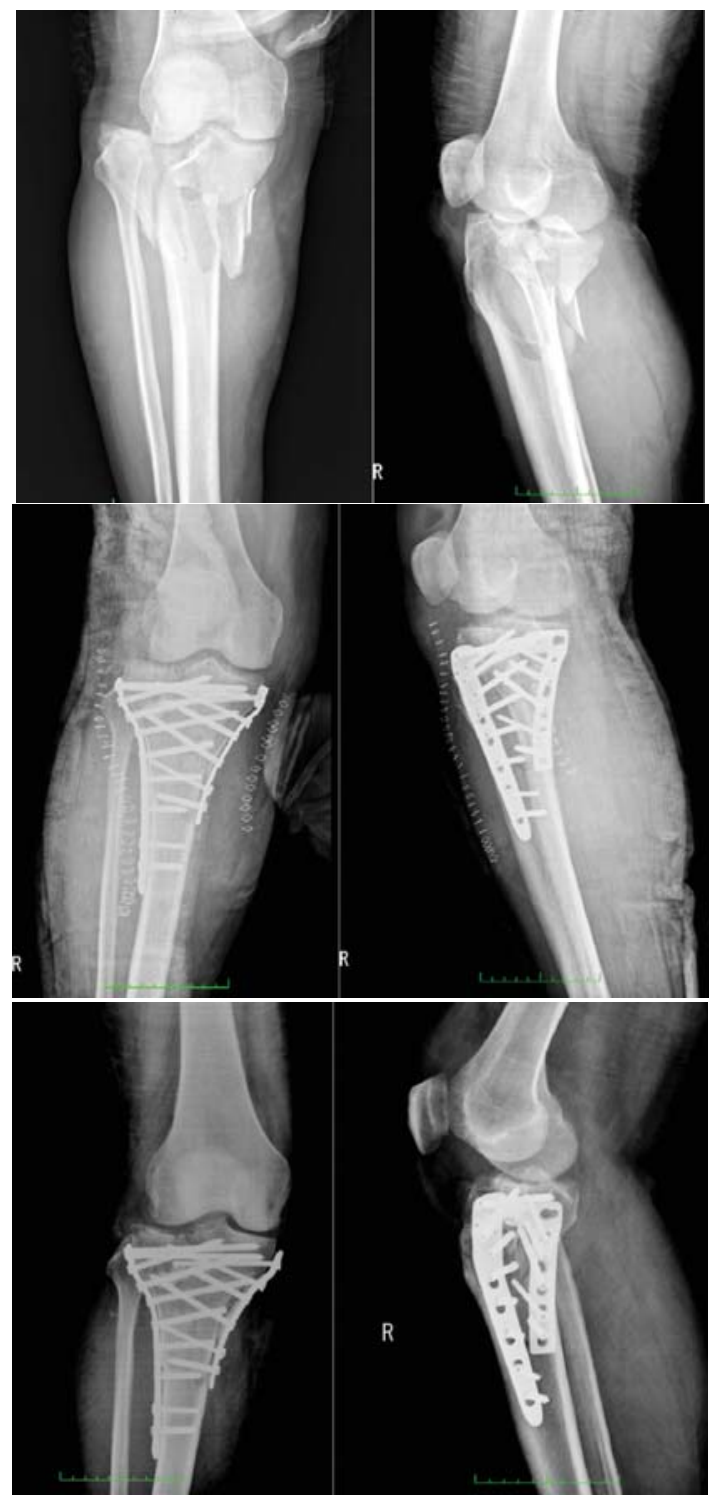




\title{
Sažetak
}

\section{UPOREĐIVANJE REZULTATA HIRURŠKOG TRETMANA I KLINIČKIH I RADIOLOŠKIH NALAZA KOD PRELOMA TIBIJALNOG PLATOA}

\author{
Kehribar Lokman, ${ }^{1}$ Karapinar Levent ${ }^{2}$ \\ ${ }^{1}$ Department of Orthopedics and Traumatology, Gazi State Hospital, Samsun, Turkey \\ ${ }^{2}$ Tepecik Training and Research Hospital Izmir, Turkey
}

Uvod: U ovoj retrospektivnoj studi, cilj je bio da se ispita korelacija između rezultata operativnog tretmana i kliničkih i radioloških nalaza kod preloma platoa tibije.

Pacijenti i metode: U periodu od 1996. do 2006. godine, 33 kolena su operisana zbog preloma platoa tibije kod 32 pacijenta. 29 pacijenata su bili muškog pola, a troje je bilo ženskog. Samo 3 slučaja (9.99\%) je imalo otvoreni prelom platoa tibije. Prosečna starost iznosila pacijenata je bila 45 godina. Prelomi su klasifikovani koristeći Schatzker klasifikaciju i pokazali su sledeće rezultate: 17 (52\%) imalo je tip 1, 12 $(12 \%)$ je imalo tip 2, $9(27 \%)$ tip 5 i $6(9 \%)$ imalo je tip 6. Pacijenti su praćeni u periodu od minimum 44 nedelje, maksimalno 480 nedelja (srednja vrednost je 60 nedelja).

Rezultati: Rezultati 33 operisana kolena su utvrđeni na osnovu kliničkog i radiološkog sistema Rasmussen. Prateći kliničke nalaze, 17 slučajeva se od-

\section{REFERENCES}

1. Pean CA, Driesman A, Christiano A, Konda SR, Davidovitch R, Egol KA. Functional and clinical outcomes of nonsurgically managed tibial plateau fractures. J Am Acad Orthop Surg. 2017; 25(5): 375-80.

2. Schatzker J, McBroom R, Bruce D. The tibial plateau fracture. The Toronto experience 1968-1975. Clin Orthop Relat Res. 1979 (138): 94-104.

3. Abdel MP, von Roth P, Cross WW, Berry DJ, Trousdale RT, Lewallen DG. Total knee arthroplasty in patients with a prior tibial plateau fracture: a long-term report at 15 years. J Arthroplasty. 2015; 30(12): 2170-2.

4. Singleton N, Sahakian V, Muir D. Outcome after tibial plateau fracture: how important is restoration of articular congruity? J Orthop Trauma. 2017; 31(3): 158-63.

5. Cooper A, Tyrrell F. The lectures of Sir Astley Cooper on the principles and practice of surgery: Sherman; 1826.

6. Van Dreumel R, Van Wunnik B, Janssen L, Simons P, Janzing H. Mid-to long-term functional outcome after open reduction and internal fixation of tibial plateau fractures. Injury. 2015; 46(8): 1608-12.

7. Musahl V, Tarkin I, Kobbe P, Tzioupis C, Siska P, Pape $\mathrm{H}-\mathrm{C}$. New trends and techniques in open reduction and internal fixation of fractures of the tibial plateau. J Bone Joint Surg Br. 2009; 91(4): 426-33. lično oporavilo, 9 je bilo dobro, 6 je bilo osrednjje i 1 je bio loš. Prema radiološkim nalazima, 9 slučajeva je bilo u odličnom stanju, 16 je bilo dobro, 6 je bilo osrednje i 2 su bila lošeg stanja. Razlika između kliničkih i radioloških nalaza je analizirana Pirsonovom core analizom i određivana je statistička značajnost $(\mathrm{p}<0,005)$. Razlika je određivana prema vremenu između povrede i operacije i nije nađena nikakva statistička značajnost $(\mathrm{p}>0,005)$. Analize stadijuma i stepena preloma su pokazale statističku značajnost među grupama ( $\mathrm{p}>$ 0,005). 42,4\% svih pacijenata je imalo povredu meniskusa. S toga, artroskopija bi trebalo da se koristi u operativnom lečenju ovog oboljenja.

Zaključak: Anatomska redukcija, rigidno fiksiranje zgloba i rana mobilizacija mogu da smanje nivo komplikacija i da poboljšaju funkciju zgloba kolena kod preloma platoa imatibije.

Ključne reči: anatomska redukcija, prelom platoa tibije, hirurgija.

8. Su EP, Westrich GH, Rana AJ, Kapoor K, Helfet DL. Operative treatment of tibial plateau fractures in patients older than 55 years. Clin Orthop Relat Res. 2004; 421: 240-8.

9. Chauhan A, Slipak A, Miller MC, Altman DT, Altman GT. No Difference Between Bracing and No Bracing After Open Reduction and Internal Fixation of Tibial Plateau Fractures. JAAOS-Journal of the American Academy of Orthopaedic Surgeons. 2018; 26(6): e134-41.

10. Shrestha R, Kandel M, Gupta HK, Shrestha SK, Dongol S, Hamal RR. A study of conservative management of tibial plateau fractures. Journal of College of Medical Sciences-Nepal. 2016; 12(1): 5-9.

11. Chen XZ, Liu CG, Chen Y, Wang LQ, Zhu QZ, Lin P. Arthroscopy-assisted surgery for tibial plateau fractures. Arthroscopy. 2015; 31(1): 143-53.

12. Warner SJ, Garner MR, Schottel PC, Fabricant PD, Thacher RR, Loftus ML, et al. The effect of soft tissue injuries on clinical outcomes after tibial plateau fracture fixation. J Orthop Trauma. 2018; 32(3): 141-7.

13. Li D, Fang Y, Liang Y, Ma K, Zou C. Postoperative computed tomography evaluation of posterior tibial plateau fractures: mean 7-Year clinical follow-up. J Knee Surg. 2018; 31(7): 670-6.

14. Patel P, Trivedi K, Kumar P, Mehrotra R, Chaudhary D, Chaudhary P, et al. Assessment of Functional and Radiological Outcome of Proximal Lateral Condyle Fracture of Tibia (Schatzker Type 1, 2 and 3) Fixed with Locking Compression 
Plate and Screw. Indian Journal of Public Health Research \& Development. 2018; 9(5): 279-83.

15. Blokker CP, Rorabeck CH, Bourne RB. Tibial plateau fractures. An analysis of the results of treatment in 60 patients. Clin Orthop Relat Res. 1984; 182: 193-9.

16. Rasmussen PS. Tibial condylar fractures: impairment of knee joint stability as an indication for surgical treatment. J Bone Joint Surg Am. 1973; 55(7): 1331-50.

17. Stevens DG, Beharry R, McKee MD, Waddell JP, Schemitsch EH. The long-term functional outcome of operati- vely treated tibial plateau fractures. J Orthop Trauma. 2001; 15(5): 312-20.

18. Kayıran E, Orhan Z, Parmaksızoğlu A, Erdemir A. Yazıcı N. Tibia plato kırıklarının cerrahi tedavisinde sonuçları etkileyen faktörler. Acta Orthop Traumatol Turc. 2000; 34: 34-9.

19. Papagelopoulos PJ, Partsinevelos AA, Themistocleous GS, Mavrogenis AF, Korres DS, Soucacos PN. Complications after tibia plateau fracture surgery. Injury. 2006; 37(6): 475-84.

\section{Correspondence to/Autor za korespondenciju}

Lokman Kehribar

Gazi State Hospital, Department of Orthopedics and Traumatology

Samsun, Turkey

e-mail: lokmankehribar@gmail.com

GSM: +90 5535903729 